
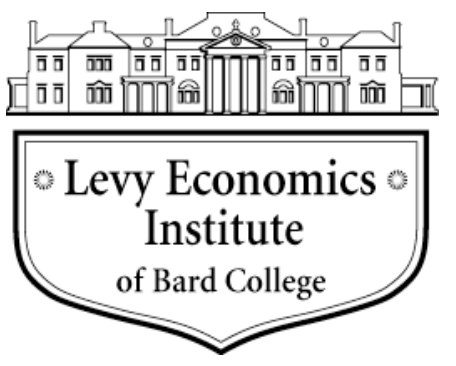

Working Paper No. 890

\title{
On the Centrality of Redemption: Linking the State and Credit Theories of Money through a Financial Approach to Money
}

\author{
by \\ Éric Tymoigne * \\ Levy Economics Institute of Bard College
}

May 2017

* Correspondence: etymoigne@lclark.edu

The Levy Economics Institute Working Paper Collection presents research in progress by Levy Institute scholars and conference participants. The purpose of the series is to disseminate ideas to and elicit comments from academics and professionals.

Levy Economics Institute of Bard College, founded in 1986, is a nonprofit, nonpartisan, independently funded research organization devoted to public service. Through scholarship and economic research it generates viable, effective public policy responses to important economic problems that profoundly affect the quality of life in the United States and abroad.

Levy Economics Institute

$$
\text { P.O. Box } 5000
$$

Annandale-on-Hudson, NY 12504-5000

http://www.levyinstitute.org

Copyright (C) Levy Economics Institute 2017 All rights reserved 


\begin{abstract}
The paper presents a financial approach to monetary analysis that links the credit and state theories of money. A premise of the functional approach to money is that "money is what money does." In this approach, monetary and mercantile mechanics are conflated, which leads to the conclusion that unconvertible monetary instruments are worthless. The financial approach to money strictly separates the two mechanics and argues that major monetary disruptions occurred when the two were conflated. Monetary instruments have always been promissory notes. As such, their financial characteristics are central to their value and liquidity. One of the main financial requirements of any monetary instrument is that it be redeemable at any time. As long as this is the case, the fair value of an unconvertible monetary instrument is its face value. While the functional approach does not recognize the centrality of redemption, the paper shows that redemption plays a critical role in the state and credit views of money. Payments due to issuer and/or convertibility on demand are central to the possibility of par circulation. The paper shows that this has major implications for monetary analysis, both in terms of understanding monetary history and in terms of performing monetary analysis.
\end{abstract}

Keywords: Credit Theory of Money; State Theory of Money; Net Present Value; Monetary Systems

JEL Classifications: E31, E42, G12 


\section{INTRODUCTION}

A premise of the functional approach to money is that one cannot define a thing as a monetary instrument independently from how economic agents use it: "money is what money does" (Walker 1878). Anything that fulfills all ("all-purpose money") or some ("special-purpose money") functions attributed to money is a monetary instrument. Mainstream economists use this approach in a narrow way by focusing on its function as a medium of exchange, and it is closely associated with the metalist view (Goodhart 2003). A proper analysis of monetary systems focuses on what people use to exchange and one may conclude that "no one invented [money], money is a natural product of human activity" (Menger, cited in Desan [2016]). Ultimately, however, money is neutral and the equilibrium price of money can be zero in a generic general equilibrium model. Accordingly, Turner (2015) states that the net present value of the monetary base is zero.

The net present value of monetary instruments is their face value, not zero. They circulate at that price as long as a proper financial infrastructure is in place, as long as the issuer is credible, as long as proper redemption mechanisms are in place, and as long as monetary instruments are set up properly. To explain this, quite a few economists and non-economists have noted the centrality of the issuer's promise of redemption. Some analyze how taxes give a non-zero price to monetary instruments (Starr 1974; Wray 1998; Knapp 1905; Desan 2016), others emphasize the role of debt servicing (Smith 1832; MacLeod 1889), while others have combined these and other approaches into an overall analysis of monetary systems (Aglietta, Ould Ahmed, and Ponsot 2016; Gardiner 2006; Ingham 2004; Graeber 2011).

This paper argues that redemption plays a central role in monetary analysis and that analysts who use the state and credit theories operate in a similar framework. Innes $(1913,1914)$ and Gardiner (2006) made the same point, and this paper develops it by focusing the analysis of monetary systems on the financial mechanics at play. These financial mechanics emphasize the role of trust in the issuer of a monetary instrument. They provide a point of departure to analyze the role of the socio-politico-economic forces in the determination of the nominal and real values of monetary instruments, and in explaining monetary disruptions. A proper approach to monetary 
issues does not start — or finish — by focusing on a function, but by understanding what financial characteristics make monetary instruments able to fulfill the functions attributed to them. Monetary instruments are not defined by what they do but by what they are - promissory notes with specific financial characteristics.

After fleshing out the financial approach to money, this paper shows how it is common to the "credit view" and the "state view," and how this approach is used implicitly or explicitly by circuitists, post Keynesians, and regulationists.

\section{MONETARY INSTRUMENTS: A SPECIFIC PROMISSORY NOTE}

Anybody can make any kind of promise: "I will pick you up tonight at 8pm"; "I will do my homework tomorrow"; "I will provide you a free pizza whenever you want"; "I will service my mortgage every month for the next 30 years." The hard parts are, first, to convince others of the genuineness of the promise so they are willing to accept it and, second, to fulfill the promise once it has been accepted. If the issuer of a promise is not credible (maybe he has a reputation for being late and lazy, or maybe he defaulted on past debts), there is much less chance that the promise will be accepted or it will be accepted only at a high cost to the issuer.

Some promises are casual, while others are formal, but all of them involve trust in the ability and willingness of the issuer of a promise to fulfill that promise. Promissory notes are formal promises that carry the weight of the law, either through contractual agreements or through legislations (Desan 2016). A promissory note may be financial or nonfinancial depending on the nature of the promise made. A free-pizza coupon is a nonfinancial promissory note, while a mortgage note merely involves future monetary transfers. The world of finance establishes a legal framework to record the creation and fulfillment of formal promises that are financial in nature. Finance measures more or less accurately the credibility of these financial promises by pricing promissory notes ("financial instruments") that embed these promises. 
The way a promissory note is structured varies widely depending on the needs of their issuer, but common questions that a promise must answer are:

- Who is the issuer? That is, who made the promise?

- The mark of the issuer (name, portrait, etc.) is present so bearers know who is supposed to fulfill the promise embedded in the promissory note.

- What is the unit of account?

- Promissory notes cannot exist before there is a unit of measurement for transactions and outstanding balances.

- When will the issuer take back its promissory note? That is, how long will it take the issuer to fulfill the promise?

- There is a term to maturity. At maturity, the issuer must take back the promissory note it issued (and then destroy it to make sure nobody can reacquire it to have a claim on the issuer). The term can go from zero (issuer takes back its promissory note at the bearer's discretion) to infinity (issuer takes back its promissory note at its discretion).

- At what price will the issuer take back its promissory note?

- A face value specifies the number of units of account the promissory note carries.

- How will the issuer take back its promissory notes? How can bearers redeem the notes?

- This deals with the expected means that will be used by the issuer to fulfill their promises, also called the "reflux mechanisms/channels."

- What is (are) the benefit(s) for those willing to trust the issuer?

- These benefits could include gaining an income, voting rights, settling debts owed to issuer, avoiding prison, etc.

- Are there any protections for bearers in case the issuer is unable or unwilling to fulfill the promise?

- Promissory notes may be secured.

- Is it possible to transfer the promissory note to another bearer?

- Promissory notes may be negotiable; that is, the person to whom the promise has to be fulfilled can be changed by transferring ownership of the promissory note. Some promissory notes are not transferable because they name the beneficiary 
(e.g., savings bonds issued by US Treasury) and cannot be endorsed to someone else. Some, like checks, have limited transferability through endorsement.

Depending on how these questions are answered, the name of a promissory note changes. A Treasury bill does not provide any reward and is due within a year. A common share provides a reward depending on the profit of the issuing company and gives a voting right, but the company does not promise to take back its shares. Within a country, there is a hierarchy of promissory notes in the sense that some are more easily accepted (Bell 2001; Murad 1954; Innes 1913). The most widely accepted promissory notes are negotiable, of the highest creditworthiness, of the highest liquidity, and of the shortest term to maturity. Some issuers make the following promise to bearers:

- I will take back my promissory note whenever you want me to do so, i.e., the term to maturity is instantaneous/zero, and the promissory note is redeemable at any time.

- I will take back my promissory note from anybody who presents it to me, i.e., only the issuer's mark is on the instrument and no beneficiary is named (either no name or "the bearer").

- I will take back my promissory note at par in payments owed to me, i.e., by handing me my promissory note, I will reduce any debt you owe me by the face value of the note.

The promise may contain two additional clauses:

- I will exchange my promissory note for something else whenever the bearer wants me to do so, i.e., there is a clause that promises convertibility at any time.

- I will use a given weight and fineness of a precious metal to make the promissory note, i.e., the promissory note is secured.

This type of promissory note is a monetary instrument, which depending on the availability of the last two clauses may be unsecured and unconvertible, secured and convertible, or a mix of the two. An inability or unwillingness to fulfill any part of this promise involves default by the issuer, which affects the value of the note (as explained below). 
In the financial approach to money, the previous questions are the guiding framework for monetary analysis. The point is to explain how these questions are answered in order to determine which promissory notes are monetary instruments and to analyze why a monetary system may or may not work properly (hyperinflation, financial instability, circulation at premium or discount, among others). The following shows how this is done conceptually, while authors cited in the introduction provide a historical analysis of monetary issues based directly or indirectly on these questions (see also Desan [2010] and Tymoigne [2014]).

\section{SOME IMPLICATIONS FOR THE FINANCIAL ANALYSIS OF MONETARY SYSTEMS}

\section{Value of a Monetary Instrument}

Monetary systems are composed of two essential elements: a unit of account and some monetary instruments denominated in that unit. The value of a monetary instrument changes for two reasons, either its nominal value changes or the value of the unit of account changes.

In terms of nominal value, a promise is as good as the credibility of the issuer and the benefits the promise provides to bearers. As such, the valuation of any promissory note depends on the expected ability and willingness of the issuer to fulfill what it promised to do. For financial instruments, the promise takes the form of future monetary commitments and the point of finance is to determine their present value. The nominal value, $P$, at which a promissory note ought to circulate among bearers is called the "fair price" or "fair value":

$$
P_{t}=\sum_{n=1}^{N} \frac{E_{t}\left(Y_{n}\right)}{\left(1+d_{t}\right)^{n}}+\frac{E_{t}\left(F V_{N}\right)}{\left(1+d_{t}\right)^{N}}
$$

Where the subscript $t$ indicates the present time; $P_{t}$ is the current fair value; $Y_{n}$ is the nominal income promised at a future time $n ; F V_{N}$ is the face value that will prevail at maturity; $E_{t}$ indicates current expectations of bearers about income and face value of time $n$; $d_{t}$ is the current discount rate imposed by bearers; and $N$ is the term to maturity ( $n=0$ is the issuance time). 
A wide variety of promissory notes are priced according to this formula, and they can be classified as promissory notes according to the term to maturity. At one extreme are modern government monetary instruments that promise no income $(Y=0)$, are redeemed at the discretion of bearers $(N=0)$, and are expected to be taken back by the government at their initial face value at any time, i.e., $P_{t}=F V_{0}$. Government monetary instruments ought to circulate at par all the time because they are zero-term, zero-coupon promissory notes. At the other extreme are consols that have a given expected income and are redeemed at the discretion of the issuer, i.e., $(N \rightarrow \infty)$, $P_{t}=E_{t}(Y) / d_{t}$. They are infinite-term, positive-coupon promissory notes. In case of default, the fair value depends on the expected ability of bearers to recover some of the unpaid dues embedded in the promise. The fair value is equal to the expected value of the collateral and available recourses discounted back to the present.

For example, say that company $\mathrm{X}$ issues 3 -year bonds with a face value of $\$ 1,000$ and a coupon rate of 10 percent. This means that company $\mathrm{X}$ will buy back its bonds for $\$ 1,000$ in three years and will pay a $\$ 100$ coupon during three years. Depending on the value of $d$, the bond circulates at a discount, at parity, or at a premium. The value of $d$ depends on several factors, such as default risk; the higher the probability that coupons and/or principal will not be paid, the steeper the discount rate, and so the further below par the 3-year bond trades. For a $\$ 20$ unconvertible Federal Reserve note (FRN), the government does not promise any coupon and promises to take back the FRNs at any time at $\$ 20$, so the discount factor does not matter because the term to maturity is instantaneous. The $\$ 20 \mathrm{FRN}$ ought to trade at parity at all times.

The previous examples assume that the issuer does not default. Assume that right after the issuance of the 3-year bonds, company $\mathrm{X}$ announces that it cannot make the promised payments. Negotiation with bondholders leads to an agreement that company X will pay $\$ 70$ coupons and $\$ 500$ of principal, which pushes down the fair price of the bond. Again, the fair value depends on $d$ that must have increased. The same applies to FRNs. If the government announces it only accepts $\$ 20$ FRNs at $\$ 10$ at any time, that is, a \$20 FRN only redeems \$10 of debts owed to the government, the new face value is $\$ 10$. In the economy, the $\$ 20$ circulates among bearers at $\$ 10$. Shops take the $\$ 20$ note only for $\$ 10$ worth of items, banks that receive a $\$ 20$ note only credit $\$ 10$ to the bank accounts of the depositor, and repaying bank debts with a \$20 FRN only clears 
$\$ 10$ of bank debts. At the time of default, bearers of FRNs record a 50 percent haircut. This may seem strange but only because we are no longer accustomed to this. In the past, kings used to change the face value of their coins frequently or establish a floating denomination for their coins. Until the late 19th century, private bank notes were applied a discount that varied over time in part because of the changing creditworthiness of private banks.

A central question of monetary analysis is to explain why a monetary instrument does, or does not, circulate at parity: what makes a monetary instrument perfectly liquid? This explanation should emphasize the financial characteristics of the monetary instrument, the trust in the issuer, the redemption mechanisms, and the financial infrastructure in place. Tymoigne (2014) explains why the circulation price of monetary instruments deviated from their fair price in the past.

The previous point deals with changes in the nominal value of a specific promissory note. There are situations in which the value of all promissory notes changes at the same time relative to the value of goods and services (output-price inflation or deflation) or relative to another unit of account (exchange-rate depreciation or appreciation). These changes in purchasing power are due either to the decisions of a monetary authority or to mechanisms at work in a monetary system. Why these changes occur has been thoroughly explained, so this paper will not develop this point (see chapter 7 of Minsky [1986]).

Changes in the value of the unit of account should be differentiated from changes in the fair value of monetary instruments. While both changes lead to the same result (changes in purchasing power), the mechanisms at play are different. Changes in the value of the unit of account relate to expected and actual changes in macroeconomic conditions. Changes in the fair value relate to expected and actual changes in the characteristics of a promissory note (e.g., default, rise in intrinsic value) or in the financial infrastructure (e.g., disruption in the payment system). For banks and government monetary instruments, this second type of change has not occurred since government guarantees have been put in place, interbank bank settlement at par has been done efficiently, and inconvertible government monetary instruments have become common and their supply made elastic. 


\section{Demand for Monetary Instruments: Why Are They Accepted?}

In the same way anybody can make any kind of promise, anybody can create monetary instruments given that they are just a specific form of promise. The problem, as Minsky (1986: 228) noted, is to get others to accept them. Given that the nominal value of a monetary instrument rests on the credibility of the issuer, acceptance of that monetary instrument introduces the central role of trust for a well-functioning monetary system. Whenever there is a promise, there is trust, but one needs to be careful when explaining how trust matters. The answer to "why do you accept a \$20 note at \$20?" is usually "because I trust others to do so at \$20." The problem with this answer, beyond its circularity, is that a promise to do something is only as credible as the economic unit who makes that promise. As such, acceptance of a promise must have something to do with the credibility of the originator of the promise. Even acceptance of a promise as trivial as "I will pick you up tonight" requires that the person to whom the promise is made perceives it as credible; otherwise, the person will refuse and call a cab. Going back to the fair value example presented above, if company X now declares it cannot make any of the payments owed on the bond, the fair value of the bond is $\$ 0$ - there is no demand for the bond - unless bondholders have the ability to seize assets of company $\mathrm{X}$ or have other forms of recourses. Similarly, if the government states that it will not accept its $\$ 20$ FRN whenever it is presented by bearers, the fair price of the $\$ 20 \mathrm{FRN}$ is now $\$ 0$ - the demand for it falls to nothing. There is a complication for FRNs because they are secured by the assets of the Fed, therefore during the time of legal proceedings FRNs ought to have a value equal to the expected value of the assets that back the FRNs.

While no bearer of monetary instruments usually thinks about the ability to pay the issuer, this is not unique to monetary instruments. Most bearers of financial instruments pay no attention to the credibility of the issuer, but rather focus on the expected direction of the nominal price of the promissory note. Most bearers of shares hold them because they expect the price to increase. Most, if not all, bearers expect the nominal price of monetary instruments to be unchanged, which is what is attractive about that type of financial instrument as long as inflation is contained. The crucial role of the issuer is revealed in times of an adverse financial event related to the issuer. If a company becomes insolvent, the nominal value of its shares goes to zero; if the issuer of a monetary instrument decides to lower the face value of its monetary instrument, the 
fair price falls to the new face value. The credibility of the issuer, if strong, creates an anchor toward which bearers' expectations about $Y$ s and $F V$ converge. This provides a stable nominal value for monetary instruments, which is crucial for a well-functioning monetary system.

Thus, while societal trust (trust of bearers about other bearers' willingness to hold a monetary instrument) may help promissory notes circulate more broadly, the trust at the core of the circulation of a promissory note is the financial credibility of the issuer (trust of bearers about the issuer's willingness and ability to fulfill its promise). Without the latter, the fair value of an unsecured nonrecourse inconvertible promissory note falls to zero.

For the government, the foundation of this trust is the political legitimacy and/or authority perceived by bearers. This sovereignty expresses itself via the ability of the government to impose a debt (tax, fee, fine, tribute, etc.) on its population, the ability to enforce that debt, and the ability to punish those who do not pay the debt. The government promises that its monetary instruments can be used at par and at any time to pay the debt. If sovereignty is weak, and so does not enforce the debt, bearers may not accept government monetary instruments or may accept them only at a discount. If sovereignty is strong but there are not enough government monetary instruments available to fulfill tax payments, then they may circulate at a premium (Hawtrey 1919: 176). If the government is strong and did provide enough monetary instruments to fulfill tax payments, but payments are only due occasionally, an unconvertible monetary instrument cannot be returned at the discretion of the bearers. Thus, in order for a government monetary instrument to work smoothly, the taxation promise of a government needs to be credible, payments to the government must be owed at any time or conversion on demand at par into an unconvertible monetary instrument must be possible, and finally a government needs to provide enough monetary instruments to the population to pay the tax and must accept them at par. Usually the population also wants to save government monetary instruments for uses beyond taxes, so a government ought to run a deficit. The case of the Massachusetts colonies is a good example of the tension that exists between the need to tax to maintain the stability of the monetary system and the need to fulfill the desired hoarding of government monetary instruments (Tymoigne 2014). 
For banks and other private issuers, the foundation of this trust rests on their ability to impose a debt on others, to enforce that debt, and to punish debtors if the debt is not paid. Most bank monetary instruments are created simultaneously with the creation of a nonbank debt and most monetary creation by banks involves an exchange of promissory notes - one with a positive maturity (mortgage notes, among others) and one with an instantaneous maturity (bank deposits, private banknotes). Bank monetary instruments are in high demand because banks are dealers in promissory notes. As such, at any time, banks have a high number of economic agents who need to make payments to banks and who can use bank monetary instruments at par to make those payments.

Thus, the monetary instruments of an issuer are broadly accepted for two central reasons: one is because the issuer has a large number of debtors, and, two, because bearers trust the issuer will accept its monetary instrument at par when they pay the issuer. Given the size of the pool of debtors, another way to broaden acceptance is to promise conversion at any time into something desirable (like precious metal or a foreign currency) or to provide some collateral. The case of precious metal coins is discussed more carefully below.

\section{Convertible versus Redeemable}

In the literature dealing with monetary mechanics, there is some confusion between redeemability and convertibility. For example, Turner (2015) argues that the "monetary base is an asset for the private sector, but for the government it is a purely notional liability (with NPV [net present value] equal to zero) since it is irredeemable and non-interest-bearing." Monetary instruments are like consols, so their fair value is $P=Y / d$ and so equal to zero because monetary instruments pay no income.

A well-functioning monetary system requires that the monetary base be redeemable on demand. To be redeemable a monetary instrument does not have to be convertible, it only has to be returnable to the issuer. This is the case if the issuer promises to accept their monetary instrument at par at any time in payments of debts owed to the issuer, and if some payments are due at any time to the issuer so that the promised term to maturity can be implemented. An issuer may also promise redemption through convertibility in order to enhance acceptance, especially if 
the promise of redemption through payments to the issuer is perceived to be weak by bearers. For example, US gold certificates are redeemable even though they are no longer convertible in gold:

\begin{abstract}
Although gold certificates are no longer produced and are not redeemable in gold, they still maintain their legal tender status. You may redeem the notes you have through the Treasury Department or any financial institution. The redemption, however, will be at the face value on the note. These notes may, however, have a "premium" value to coin and currency collectors or dealers. (US Treasury 2011)
\end{abstract}

One can redeem them at the US Treasury to pay debts owed to the US Treasury (either directly or through banks) or to get Federal Reserve notes, but only at face value, which is their value as monetary instruments although their value as collectible items is sometimes much higher.

As such, the net present value of a monetary instrument is not zero but the price at which an issuer promises to redeem its monetary instruments (the face value). In the past, some governments did forget to include, or removed, a redemption clause (Smith 1832: 49;

Langworthy Taylor 1913: 309). Some governments did have a redemption clause but defaulted on it because they could not, or would not, implement it in terms of price (redemption at face value) and/or in terms of term to maturity (redemption at any time). For example, there were no or very limited redemption mechanisms for continentals (Wright 2008). Colonies issued unconvertible bills of credit that they promised to redeem at any time but then postponed tax enforcement or did not tax at all (Tymoigne 2014). In China, paper money issued in the 13th century was not always redeemable at will through conversion or tax payment (Graeber 2011: 270). In that case, the fair value of a monetary instrument is discounted to account for the expected time to redemption.

\title{
Fiat Money versus Commodity Money: A False Dichotomy
}

One may wonder if, and how, the previous framework applies to precious metal coins. Von Mises makes a distinction between fiat money that circulates at a value determined by decree/stamping, and commodity money that circulates at its intrinsic value (monetary value of the commodity). He argues that the difference is important because most precious metal coins 
used to circulate at their weight, even when a decree existed and especially if people did not agree with the decree because of debasement (von Mises 1912).

This distinction is not useful for both conceptual and historical reasons. In historical terms, recent numismatic research concludes that, within the sphere of influence of its issuer, coins usually circulated at their decreed face value ("by tale") not their intrinsic value ("by weight") no matter how small or large the debasement was. This was the case at least in ancient Greece (Peacock 2006), Roman times (Wolters 2012; Harris 2008), ancient China (Thierry 1993), and medieval times (Allen 2016), where the emphasis was on counting the coins for payments. Of course, this does not deny that at times coins circulated above or below their face value, but that can be explained by improper financial mechanics because of an inadequate financial infrastructure, problems with the issuer's credibility and redemption mechanisms, or improper financial characteristics of the monetary instruments (Desan 2010; Tymoigne 2014). The financial mechanics were absent or inadequate to implement the decree. Outside the issuer's area of influence, bearers treated coins as merchandises and payments with them were in-kind payments.

Within the sphere of influence of the issuer, weighing (and/or cutting or chopping to check fineness) still occurred for several reasons. First, sometimes issuers resorted to a floating denomination to offset the rise in the prices of precious metal. The face value was declared to be whatever the prevailing intrinsic value was in order to lower the incentive to melt or export coins. This is an alternative to debasing coins - usually gold coins - because of their perceived centrality to the monetary standard (Eagleton and Williams 2007: 58). Second, some wanted to check the quality of the collateral, either because they did not trust the stamp of the issuer that was supposed to vouch for the fineness and weight, or because they were afraid that the quality had declined through wear and tear or illegal debasement (Eagleton and Williams 2007: 27, 165, 246). Third, the issuer checked the weight of their coins before accepting them at face value in payments to make sure nobody tampered with them and refused coins that were altered. This incentivized bearers to weigh coins before accepting them at face value (Wray 2012). Fourth, the face value of coins used not to be stamped but rather "was carried out by royal proclamation in all the public squares, fairs, and markets, at the instigation of the ordinary provincial judges: 
bailiffs, seneschals, and lieutenants" (Boyer-Xambeu, Deleplace, and Gillard 1994: 47). With frequent crying of the coinage, nobody knew what the face value was and so they circulated by weight: "there were so many edicts in force referring to changes in the [face] value of the coins, that none but an expert could tell what the [face] value of various coins of different issues were, and they became highly speculative commodities" (Innes 1913: 386). Fifth, when an economy is in the process of being monetized, people mistrust abstract monetary valuation; this is even more so when monetary instability is present. As such, they search for means (such as silver) to concretize the value of the thing used as a monetary instrument (Desan 2010). Creditors carefully checked the intrinsic weight and fineness of the coins they lent and did not care about the number of unit-of-account coins represented. From their viewpoint, they were lending a commodity (think of someone lending his car for the day) not an abstract number of a unit of account. As such, coin lenders expected to receive back the same weight and fineness of precious metal they lent (even if the price of the metal had changed), not the same amount of unit of account. After a debasement or crying up, lenders would sue borrowers if borrowers gave back a different quantity of precious metal even though coins represented the same amount of unit of account that was borrowed. From Roman times until the 16th century, when a metalist view prevailed in civil law, lenders tended to win in court (Dondorp 2016). This influenced the value at which bearers would accept coins and debasement could lead to discount trading. Where nominalism prevailed — which was the case in common law as early as the 13th century — kings issued decrees to fight discount trading with more or less success. Enforcements in courts helped to promote par trading as a norm (Fox 2016). Finally, errors in the establishment of the denominational system, as well as differences between the mint price and market price for metals, would lead bearers to make arbitrages in terms of metals with the goal of obtaining more units of a unit of account (Desan 2010: 403). For example, in 19th century China, there was enough copper in a 1-cash coin to make thirty 1000-cash coins and so some proceeded to profit from this by melting 1-cash coins to get 1000-cash coins (Eagleton and Williams 2007: 144). Chinese authorities were repeating an error they had made already in the 8th century BC (Thierry 1993: 6). These types of arbitrage were all the more common because they were encouraged by free coinage. 
In conceptual terms, all well-functioning monetary instruments require "fiat," that is, they require that the issuer declares what the face value of its instrument is because the face value is central to the promise made by the issuer. However, just issuing a declaration will not be enough, even with the threat of death. Bearers must have a direct incentive to accept a monetary instrument at face value. As such, the study of the redemption mechanisms put in place to implement fiat are central to monetary analysis in order to explain how and why fiat was successful at making a monetary instrument circulate at face value. If redemption mechanisms are absent or inadequate, implementing fiat is impossible.

Instead of a distinction between fiat and commodity money, a more relevant distinction is between secured and unsecured monetary instruments. Coins made of precious metals were a way to partly deal with the uncertainty surrounding the face value of coins. Coins with high precious metal content would be demanded from sovereigns that could not be trusted because they cried down too much, refused some of their coins in payments too often, did not accept coins at any time, or were too weak politically to enforce taxes. The precious metal content was not a monetary instrument but a collateral in the same way a house is not a mortgage but a collateral to the mortgage. The higher the content of precious metal relative to the face value, the more limited the capacity of kings to cry down the coinage because coins would disappear if the face value fell below the intrinsic value. More units of the unit of account could be obtained per coin by selling the precious metal instead of redeeming coins to the king. Others (e.g., mercenaries) demanded payments in such a form because they did not expect to be debtors to the king or to meet someone in debt to the king, or to meet someone who would expect to make transactions with someone else indebted to the king.

However, making coins with precious metal creates new problems for the issuer because the collateral can be readily acquired even if the issuer does not default on its promise. The dynamics of the market price of the precious metal relative to the face value would drive coins out of circulation even if the king did not change the face value and did enforce the redemption of its coinage. As the price of precious metals would push the intrinsic value of coins above the face value, coins would be melted or exported as merchandises. As such, debasement or crying 
up of the coinage was often a defensive mechanism to protect the coinage rather than a means to finance the crown (Smith 1832; Hawtrey 1919; Allen 2016).

\section{THE FINANCIAL APPROACH AND ITS LINK TO EXISTING MONEY THEORIES}

\section{The State and the Credit Views: A Subset of the Financial View}

Both the state theory and credit theory emphasize the importance of the promise of redemption made by the issuer to create and maintain a demand for its monetary instruments. The state theory of money argues that taxes play a central role in the acceptance, and so value, of monetary instruments issued by the state. By imposing a tax liability payable at par with its monetary instruments, and then enforcing that tax liability, the government creates a demand for its currency and ensures that its monetary instruments circulate at par. The credit theory of money focuses on the role of debts that must be paid to the issuer of a monetary instrument. When banks create monetary instruments, they simultaneously obtain a debt from nonbank agents that is payable at par with bank monetary instruments. The ability to pay debts owed to banks at par with their monetary instruments creates a demand for such monetary instruments and ensures that they circulate at par.

Both theories also emphasize the importance of the issuer's monopoly over the issuance and destruction of its monetary instruments. Counterfeiting should not be allowed, otherwise anybody can have a claim against the issuer: the issuer loses control over the issuance of its promissory notes, and trust (and so acceptance) in the issuer's monetary instrument declines. While one usually thinks of counterfeiting as an illegal activity that was, at times, used as an act of war (Rhodes 2012), past monetary systems used legalized counterfeiting via free coinage. Anybody could make the coins of the king provided they had the material accepted by the mint (such as gold, silver, or copper), which led to all sorts of problems, as briefly explained above, because of the conflict at play between the financial mechanics (maintenance of liquidity) and mercantile mechanics (commodity arbitrage) (Desan 2010). 
Both theories emphasize the financial nature of monetary instruments. All monetary instruments are promissory notes; that is, they embed a promise made by the issuer that may or may not be secured. Therefore, the face value of a monetary instrument becomes of crucial importance for explaining monetary dynamics. Issuers default on their promise if they do not redeem their monetary instrument at face value at any time. For the state, all this implies that a lack of political legitimacy and authority will hinder the ability of the state to manage its monetary instruments.

\section{Circuit, Post Keynesian, and Regulationist Views on Money}

The ability of a financial instrument to circulate at par at all times is of central importance for the theoretical framework based on the monetary production economy (Grazianni 2003). In a monetary production economy, monetary gains are the end goal. The economic circuit starts with money and is expected to finish with more money. This puts an emphasis on nominal values and nominal contracts and the role they play in shaping the allocation, production, and distribution of resources. The circuit approach has provided a careful analysis of the implications of this economic set up by focusing especially on the function of money as a means of payment. In a nominalist set up, which prevails today in economics as well as in the law, having monetary instruments that circulate at par at all times is central to the payment system.

In the post-Keynesian framework, the centrality of money comes from its perfect liquidity and how this liquidity helps cope with economic uncertainty (Keynes 1936). The financial framework helps in understanding why monetary assets are perfectly liquid. Post Keynesians, like circuitists, also emphasize bank monetary creation and the simultaneous creation of nonbank debts, and use stock-flow consistent models as the most recent way to formalize this point (Godley and Lavoie 2007). Minsky (1985a: 4) emphasizes the financial mechanics behind the value of monetary instruments: "In a modern capitalist system money is a debt of banks or of Treasuries and the value of money is maintained because of the need to make payments to banks and Treasuries by debtors and taxpayers."

Payments to issuers of monetary instruments maintain the value of their monetary instrument by fixing a constant nominal price and by managing inflation through the destruction of monetary 
instruments. Minsky (1985b: 13) also notices the bond-like nature of modern monetary instruments: "Money has evolved [...]; this evolution has taken place in response to profit opportunities or income expenditures preferences of units financed by money-issuing organizations. This financing relation — in which money is like a bond—is the essential reason why money in our economy is not neutral."

While Minsky focuses on modern monetary instruments, the same applies to earlier monetary instruments: they are bond-like, they are promissory notes, and so follow the laws of finance presented in the first section of this paper.

The regulationist approach (Aglietta, Ould Ahmed, and Ponsot 2016) emphasizes the role of confidence and sovereignty, which makes the financial approach a natural fit. Monetary analysis does not start with the double-coincidence-of-wants problem but with the social nature of the monetary system. Monetary systems link debtors and creditors and link the members of the country through the belief in the political validity of the state and the unity of the nation. Given its social nature, a monetary system is also a focal point through which some of the social tensions express themselves: political issues and individual choice (need for liquidity) versus social choice (need for a payment system), among others. These tensions may end up negatively impacting the confidence in a monetary system and so the value of monetary instruments.

\section{CONCLUSION}

Instead of focusing on the functions performed by monetary instruments to define them, this paper defines monetary instruments by their financial characteristics and notes that a unit of account is not a function of money but rather a necessary ingredient of a monetary system. In its monetary analysis, the paper shows that the financial approach focuses on the financial characteristics of a thing instead of asking how this thing is used. As such, trust in the issuer becomes a central component of the analysis. This trust manifests itself in terms of a stable political consensus about the sovereignty of the state and in terms of the creditworthiness of private issuers of monetary instruments. 
A stable nominal value - parity if the promise is credible, if the monetary instrument is set up correctly, if means are provided to fulfill the promise, and if the financial structure is well developed - is what allows monetary instruments to be used as a reliable means of payment, medium of exchange, and store of value (at least in the short run). By putting the emphasis on what money is and disassociating its nature from what it does, one can broaden the field of inquiry of monetary analysis to the socio-economico-political dynamics sustaining a monetary system, can ask different questions, and can make a clear distinction between in-kind payments (the realm of commodities) and monetary payments (the realm of finance). The working of a monetary system is influenced by political instability, problems in the financial structure, default, and the monetary practices of its users. These need to be studied carefully to understand major monetary trends throughout history and to avoid setting up a monetary system incorrectly. The eurozone is the most recent example of the ignorance of these elements because of the emphasis on the function of the medium of exchange at the expense of the function as a means of payment.

A final note on monetary history implied by the financial approach. Getting a payment system with smoothly working monetary instruments took millennia to develop and involved political (e.g., sovereignty), legal (e.g., nominalism versus valorism), and socioeconomic (e.g., monetization of economy) transformations and debates that became even more pressing as economies became monetized. Progress was often hindered by the strong association between monetary instruments and commodities, and so ignoring or misunderstanding the financial mechanics at play that aimed at promoting liquidity (fixed nominal value). Using the financial approach to money leads to a rereading of precoinage monetary systems and primitive money, by not relying on monetary functions to detect or define monetary instruments. Around $3000 \mathrm{BC}$ in Mesopotamia and Egypt, commodities such as silver, copper, or grains became means of payments, but they were not monetary instruments. All payments were in kind, and usually were made with other commodities valued in terms of units of accounts based on weights of silver, grain, or copper (Eagleton and Williams 2007). There surely was a unit of account but no monetary instruments (Henry 2004; Hudson and Wunsch 2004). Innes (1913) and Gardiner (2006) suggest that Babylonian clay tablets sealed in clay envelops were monetary instruments, and Goetzmann (2016) and Graeber (2011) suggests that bullaes (hollow ball-like clay envelops that served as legal and commercial documents, which were impressed with seals showing 
ownership or witness to whatever was inside) may have been protofinancial instruments. There is currently no conclusive archeological evidence for or against these interpretations, but this paper argues that these kinds of questions are not only valid but should be the way to do monetary analysis. Going back further in time, anthropologists who have used the functional approach have found many special-purpose monies, but the use of the word "money" is an improper imposition of modern thinking on very different societies. There was no issuer or no redemption mechanism. Most cases were "offerings" or "gifts" in the same way silverwares are given to newlyweds today and then passed to the next generation. There were also in-kind payments to compensate for offenses to other members (wergild), which some authors have seen as the origins of monetary systems (Grierson 1977; Graeber 2011).

Of course, there were cases in which natural resources or objects became monetized, but one cannot merely check if they fulfilled a function to conclude that was the case. Monetizing objects requires quite a bit of financial infrastructure to be put in place (Forstater 2005, 2006; Desan 2010) and one should do a careful analysis before concluding that monetization was present (Goldberg 2005). Once this is understood, one can move to the functions performed, how these functions may alter monetary mechanics, and how the financial characteristics and financial infrastructure in place allow, or do not allow, these functions to be performed (Tymoigne 2014). 


\section{REFERENCES}

Aglietta, M., P. Ould Ahmed, and J.-F. Ponsot. 2016. La Monnaie: Entre Dette et Souveraineté. Paris: Odile Jacobe.

Allen, M. 2016. "Currency depreciation and debasement in Medieval Europe." In D. Fox and W. Ernst (eds.), Money in the Western Legal Tradition. Oxford: Oxford University Press.

Bell, S.A. 2001. "The role of the state and the hierarchy of money." Cambridge Journal of Economics 25(2): 149-63.

Boyer-Xambeu, M.T., G. Deleplace, and L. Gillard. 1994. Private Money and Public Currencies. New York: M.E. Sharpe.

Desan, C. 2010. "Coin Reconsidered: The Political Alchemy of Commodity Money." Theoretical Inquiries in Law 11(1): 361-409.

_. 2016. "Money as a legal institution." In D. Fox and W. Ernst (eds.), Money in the Western Legal Tradition. Oxford: Oxford University Press.

Dondorp, H. 2016. "The effect of debasement on pre-existing debts in early modern jurisprudence." In D. Fox and W. Ernst (eds.), Money in the Western Legal Tradition. Oxford: Oxford University Press.

Eagleton, C., and J. Williams. 2007. Money: A History. Buffalo: Firefly Books.

Forstater, M. 2005. "Taxation and primitive accumulation: the case of colonial Africa." Research in Political Economy 22: 51-64

- 2006. "Tax-Driven Money: Additional Evidence from the History of Thought, Economic History, and Economic Policy.” In M. Setterfield (ed.), Complexity, Endogenous Money and Macroeconomic Theory. Cheltenham: Edward Elgar.

Fox, D. 2016. "The Enforcement of Nominal Values to Money in the Medieval and Early Modern Common Law." In D. Fox and W. Ernst (eds.), Money in the Western Legal Tradition. Oxford: Oxford University Press.

Gardiner, G.W. 2006. The Evolution of Creditary Structures and Controls. New York: Palgrave Macmillan.

Godley, W., and M. Lavoie. 2007. Monetary Economics: An Integrated Approach to Credit, Money, Income, Production and Wealth. New York: Palgrave Macmillan.

Goetzmann, W.N. 2016. Money Changes Everything: How Finance Made Civilization Possible. Princeton: Princeton University Press. 
Goldberg, D. 2005. "Famous Myths of 'Fiat Money.'” Journal of Money, Credit and Banking 37(5): 957-67.

Goodhart, C.A.E. 2003. "The two concepts of money: Implications for the analysis of optimal currency areas." In S.A. Bell and E.J. Nell (eds.), The State, the Market and the Euro: Chartalism versus Metallism in the Theory of Money. Cheltenham: Edward Elgar.

Graziani, A. 2003. The Monetary Theory of Production. Cambridge: Cambridge University Press.

Graeber, D. 2011. Debt: The First 5000 Years. Brooklyn: Melville House.

Grierson, P. 1977. The Origins of Money. London: Athlone Press.

Harris, W.V. 2008. “The nature of Roman money.” In W.V. Harris (ed.), The Monetary Systems of the Greeks and Romans. Oxford: Oxford University Press.

Hawtrey, R. 1919. Currency and Credit. New York: Longmans, Green, and Co.

Henry, J.F. 2004. “The Social Origins of Money: The Case of Egypt.” In L.R. Wray (ed.), Credit and State Theories of Money. Northampton: Edward Elgar.

Hudson, M., and C. Wunsch. 2004. Creating Economic Order. Bethesda: CDL Press.

Ingham, G. 2004. The Nature of Money. Cambridge: Polity Press.

Innes, A.M. 1913. “What is Money?” Banking Law Journal 30(5): 377-408.

—. 1914. "The Credit Theory of Money.” Banking Law Journal 31(2): 151-68.

Jevons, W.S. 1875. Money and the Mechanism of Exchange. New York: Appleton.

Keynes, J.M. 1936. The General Theory of Employment, Interest, and Money. London: Macmillan.

Knapp, G.F. (1905)1924. The State Theory of Money, English translation. London: Macmillan.

Langworthy Taylor, W.G. 1913. The Credit System. New York: Macmillan.

MacLeod, H.D. 1889. The Theory of Credit. London: Longmans, Green, and Co.

Menger, K. 1892. “On the Origin of Money.” Economic Journal 2(6): 239-55.

Minsky, H.P. 1985a. “An Introduction to Post-Keynesian Economics.” Economic Forum 15(2): $1-13$. 
_ 1985b. "Money and the Lender of Last Resort." Challenge 28(1): 12-18. 1986. Stabilizing an Unstable Economy. New Haven: Yale University Press.

Murad, A. 1954. Private Credit and Public Debt. Washington, DC: Public Affairs Press.

Peacock, M.S. 2006. "The origins of money in Ancient Greece: the political economy of coinage and exchange." Cambridge Journal of Economics 30(4): 637-50.

Rhodes, K. 2012. “The counterfeiting weapon.” Federal Reserve Bank of Richmond Region Focus 16(1): 34-37.

Schmandt-Besserat, D. 1992. Before Writing, vol. 1. Austin: University of Texas Press.

Smith, T. 1832. An Essay on Currency and Banking. Philadelphia: Jasper Hardin.

Starr, R.M. 1974. "The Price of Money in a Pure Exchange Monetary Economy with Taxation." Econometrica 42(1): 45-54.

Thierry, F. 1993. "De la nature fiduciaire de la monnaie chinoise." Bulletin du Cercle d'Etudes Numismatiques 30(1): 1-12, 24.

Turner, A. 2015. "The Case for Monetary Finance—An Essentially Political Issue.” Paper presented at the 16th Jacques Polak Annual Research Conference, November 5-6, Washington, DC. Available at:

http://www.imf.org/external/np/res/seminars/2015/arc/pdf/adair.pdf

Tymoigne, E. 2014. “A Financial Analysis of Monetary Systems.” In D.B. Papadimitriou (ed.), Contributions to Economic Theory, Policy, Development and Finance. New York: Palgrave Macmillan.

US Treasury. 2011. "Buying, Selling, Redeeming." In FAQs about Currency. Accessed January 27, 2017: https://www.treasury.gov/resourcecenter/faqs/Currency/Pages/edu_faq_currency_sales.aspx

von Mises, L. 1912. The Theory of Money and Credit, English translation. New Haven: Yale University Press.

Walker, F.A. 1878. Money. New York: Henry Holt and Co.

Wolters, R. 2012. "The Julio-Claudians." In W.E. Metcalf (ed.), Handbook of Greek and Roman Coinage. New York: Oxford University Press.

Wray, L.R. 1998. Understanding Modern Money: The Key to Full Employment and Price Stability. Northampton, MA: Edward Elgar. 
- 2012. Modern Money Theory: A Primer on Macroeconomics for Sovereign Monetary Systems. New York: Palgrave Macmillan.

Wright, R.E. 2008. One Nation Under Debt: Hamilton, Jefferson, and the History of What We Owe. New York: McGraw-Hill. 